\title{
Exploration of Potential Ore Deposits along the Cameroon Volcanic Line from Gravity and Magnetic Studies
}

\author{
Fosso Téguia M. Estelle Eric ${ }^{1,2}$, Nana Gaelle Vanessa ${ }^{1,3}$, Lepatio Tchieg Sterve Alain ${ }^{3,4}$, \\ Ntomb Biboum Edouard Olivier ${ }^{1,3}$, Eyike Yomba Albert ${ }^{2 *}$, Zanga Amougou Alain ${ }^{2}$, \\ Atéba Bekoa', Ntepe Nfomou ${ }^{1}$ \\ ${ }^{1}$ Branch for Geophysical and Volcanological Research/Institute for Geological and Mining Research, Buea, Cameroon \\ ${ }^{2}$ University of Douala, Faculty of Science, Department of Physics, Douala, Cameroon \\ ${ }^{3}$ University of Yaounde 1, Faculty of Science, Department of Physics, Yaounde, Cameroon \\ ${ }^{4}$ National Institute of Cartography, Yaounde, Cameroon \\ Email: *aeyike@gmail.com
}

How to cite this paper: Eric, F.T.M.E., Vanessa, N.G., Alain, L.T.S., Olivier, N.B.E., Albert, E.Y., Alain, Z.A., Bekoa, A. and Nfomou, N. (2020) Exploration of Potential Ore Deposits along the Cameroon Volcanic Line from Gravity and Magnetic Studies. Open Journal of Geology, 10, 1009-1026.

https://doi.org/10.4236/ojg.2020.1010047

Received: September 18, 2020

Accepted: October 27, 2020

Published: October 30, 2020

Copyright $\odot 2020$ by author(s) and Scientific Research Publishing Inc. This work is licensed under the Creative Commons Attribution International License (CC BY 4.0).

http://creativecommons.org/licenses/by/4.0/

\begin{abstract}
A gravity and magnetic study has been carried out along the continental part of the Cameroon Volcanic Line (CVL), with the aim to explore the possibility of ore's presence into the basement of this region. Different processing techniques have been applied, including the isostatic residual, the analytic signal and the Euler deconvolution to compute the Bouguer and magnetic anomalies. Following Euler solutions (result of Euler deconvolution) and the analytic signal results, four profiles crossing main structures on the isostatic residual have been used to enhance the structure of intrusions in the studied area. Despite the lack of constraints in the studied region, the results show that the basement is intruded by bodies of different density $\left(2.57 \mathrm{~g} / \mathrm{cm}^{3}\right.$ to $\left.2.87 \mathrm{~g} / \mathrm{cm}^{3}\right)$, different size and shape, with depths between 1 and 10 kilometers. These bodies have been interpreted as old rocks then as potential reservoirs of rare ores. In addition, volcanic rocks modeled have constituted potential reserves of other ores like graphite, sulfur, copper, iron.
\end{abstract}

\section{Keywords}

Ores Deposits, Cameroon Volcanic Line (CVL), Gravity, Magnetic

\section{Introduction}

Up to date, the Cameroon volcanic line (CVL) has been the subject of experiences and intense scientific studies, combining origin and tectonic activity. 
According to [1], the line represents the surface expression of a geological hotspot. [2] relates the origin of the CVL to that of the Benue Trough, and suggests that the eruptions along the line are related to the displacement of a hot lithospheric zone from beneath the trough to its present position. [3] proposed that the line resulted from a reactivation of Precambrian faults since the Cretaceous as a result of the African plate passing over the equatorial bulge. [4] Suggests that the trigger for the formation of the Cameroon volcanic line was brought about by the establishment of a new plate-wide shallow-mantle convection system under the zone of extension between a plume located at $7^{\circ} \mathrm{N} 11^{\circ} \mathrm{E}$ and the right angle bend in the African continental margin. The absence of sufficient age progression and the occurrence of sporadic magma rise along the CVL volcanic centers have favored different models for the origin of the CVL including: 1) Edge-driven convection along the northwestern flank of the Congo Craton [5] [6] [7], 2) remelting of fossil plume [8], 3) plume-plume interaction [9], and 4) decompression melting under reactivated shear zones [10]. However, despite this intense geophysical and geological activity, there is limited knowledge regarding the presence of deep magnetic rocks or possible ore deposits.

In this study, we apply the Euler deconvolution then we calculate the analytic signal of the magnetic field in order to locate different strange bodies. By using constraints from geological, geochemistry and seismic studies, a series of two and one-half dimensional (2.5D) gravity models are constructed from the isostatic residual anomaly map. The resulting models can be used in the determination of the geometrical properties of the volcanic center sources and in determining the general upper crustal structure of this section of the CVL.

\section{Geological Setting}

The Cameroon volcanic line is a chain of tertiary to recent volcanoes [11]. It is oriented $\mathrm{N} 30^{\circ} \mathrm{E}$ and several shear zones of the Pan African age segment it [12]. The continental part of CVL consists of anorogenic plutonic complexes and volcanoes of varying sizes and shapes [12]. In this part, magmas intruded into the overlying Proterozoic meta-sedimentary, meta-granitic, and granitic rocks.

The main volcanoes in the continental CVL include Mounts Etinde, Cameroon, Manengouba, Bamboutos and Oku, two main plateaus: Ngaounderé and Biu [2] [8] [13] [14] [15] [16]. They are dominantly polygenetic, and alternate with less evolved monogenetic grabens [17] [18]. Mt. Etinde is a small densely forested and highly dissected volcano located on the SW flank of Mt. Cameroon. It rises to a height of $1713 \mathrm{~m}$ and is made up almost entirely of nephelinitic lavas rich in euhedral (3-7 mm) highly zoned clinopyroxene phenocrysts [19]. Mt. Cameroon is the highest $(4095 \mathrm{~m})$ volcano in West Africa occupying a surface area of about $1300 \mathrm{~km}^{2}$ (Figure 1).

Mt. Cameroon is the only presently active member of the CVL with seven eruptions recorded in the last century, i.e., 1909, 1922, 1954, 1959, 1982, 1999, and 2000 [20] [21] [22]. It is a composite volcano made of alkaline basanitic and 


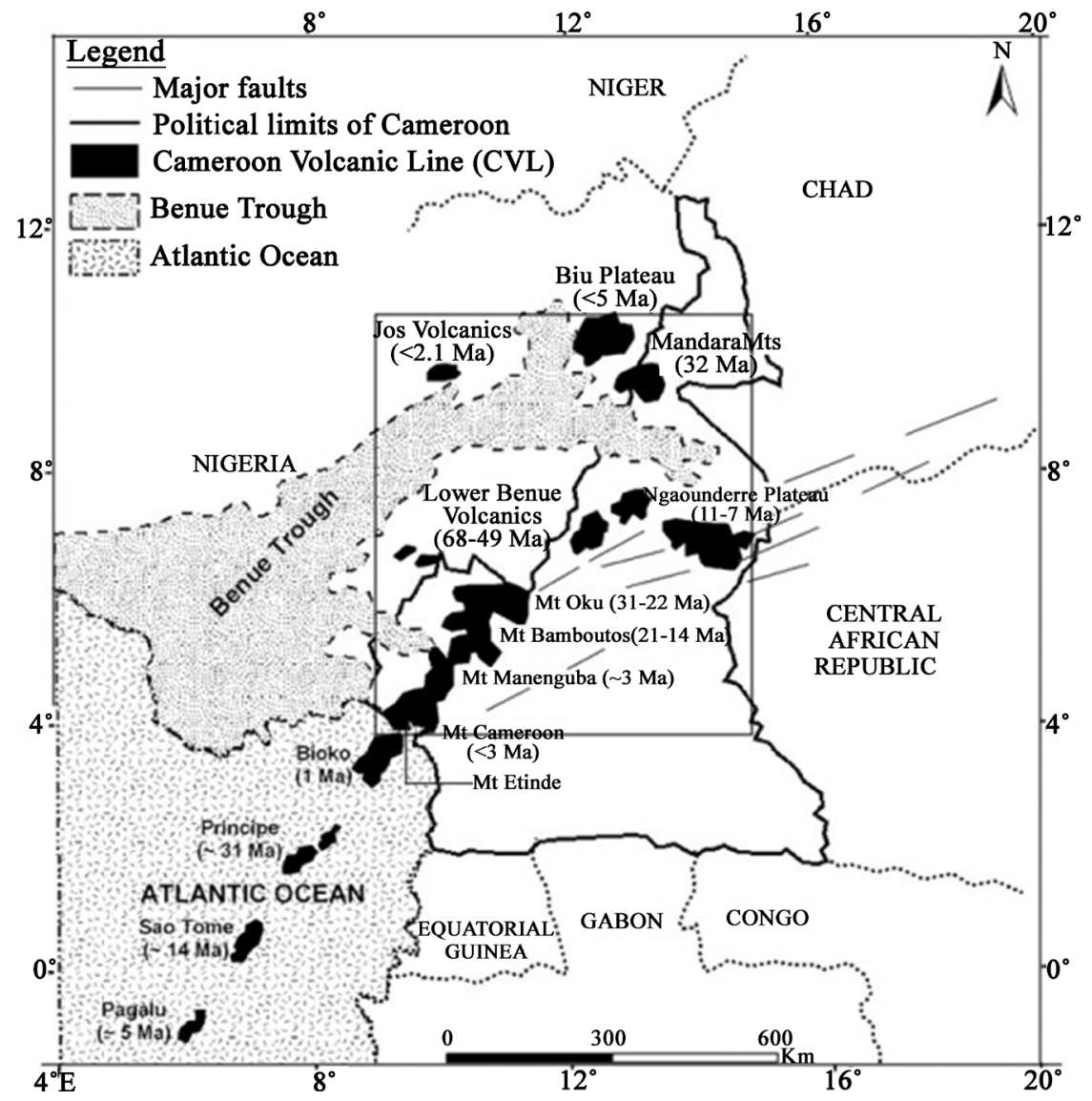

Figure 1. Geological and localization of the study area.

basaltic flows interbedded with small amounts of pyroclastic materials and numerous cinder cones [22] [23] [24].

Mt. Manengouba $(2411 \mathrm{~m})$ is a central volcano whose summit hosts two concentric calderas. With lavas that range from basalts to trachytes, quartz trachytes, and rare rhyolites [2] [25].

Mt. Bambouto $(2700 \mathrm{~m})$ and Oku $(3011 \mathrm{~m})$ are Oligocene to Quaternary stratovolcanoes with lava successions comprising a strongly bimodal basalt-trachyte-rhyolite suite [13] [26] [27] [28] [29].

The Ngaounderé Plateau, in the northeastern part of the CVL, consists of alkaline basalts and basanites capped by trachytes and phonolitic flows. The most recent volcanism in this area consists of cinder cones aligned in a WNW-ESE direction, sometimes producing small lava flows [2].

The Biu Plateau, located northward of the Ngaounderé Plateau, consists of basaltic flows with a maximum thickness of $250 \mathrm{~m}$. This plateau is composed of basanites and transitional basalts [16].

The history of tectono-magmatic activity in the CVL and adjacent Jos Plateau and the Benue Trough reveals four key points with a general age progression from the northwest to southeast. These include: 1) The initial phase of magmatic activity in the Benue Trough (147 Ma; [30]) occurred at about the same time as the emplacement of anorogenic granite ring complexes when the formation of 
the Jos plateau ended; 2) The transition from the first to second stages of magmatic activity in the Benue Trough (106 - $95 \mathrm{Ma}$ ) overlaps with the period (100 $\mathrm{Ma}$ ) when the Equatorial Atlantic opened, leading to the separation between the South American and African plates [31];3) The last stage of magmatic activity in the Benue Trough (68 - $49 \mathrm{Ma}$ ) was contemporaneous with the initial phase of intrusive activity of the continental sector of the CVL (66 - $30 \mathrm{Ma}$ ) [32]; 4) Volcanic activity in the CVL (45 Ma-present, [11] [13] [33]).

\section{Data and Processing}

\subsection{Topography}

The elevation data used were extracted from the ETOPO1 database [34]. The study area shows high topographic variations (Figure 2). The Adamawa plateau and the West's highlands are the most prominent regions but the mount Cameroon although isolated remains the highest peak of the CVL.

\subsection{Gravity}

The gravity data set stems from the Earth Gravitational Model 2008 (EGM2008;

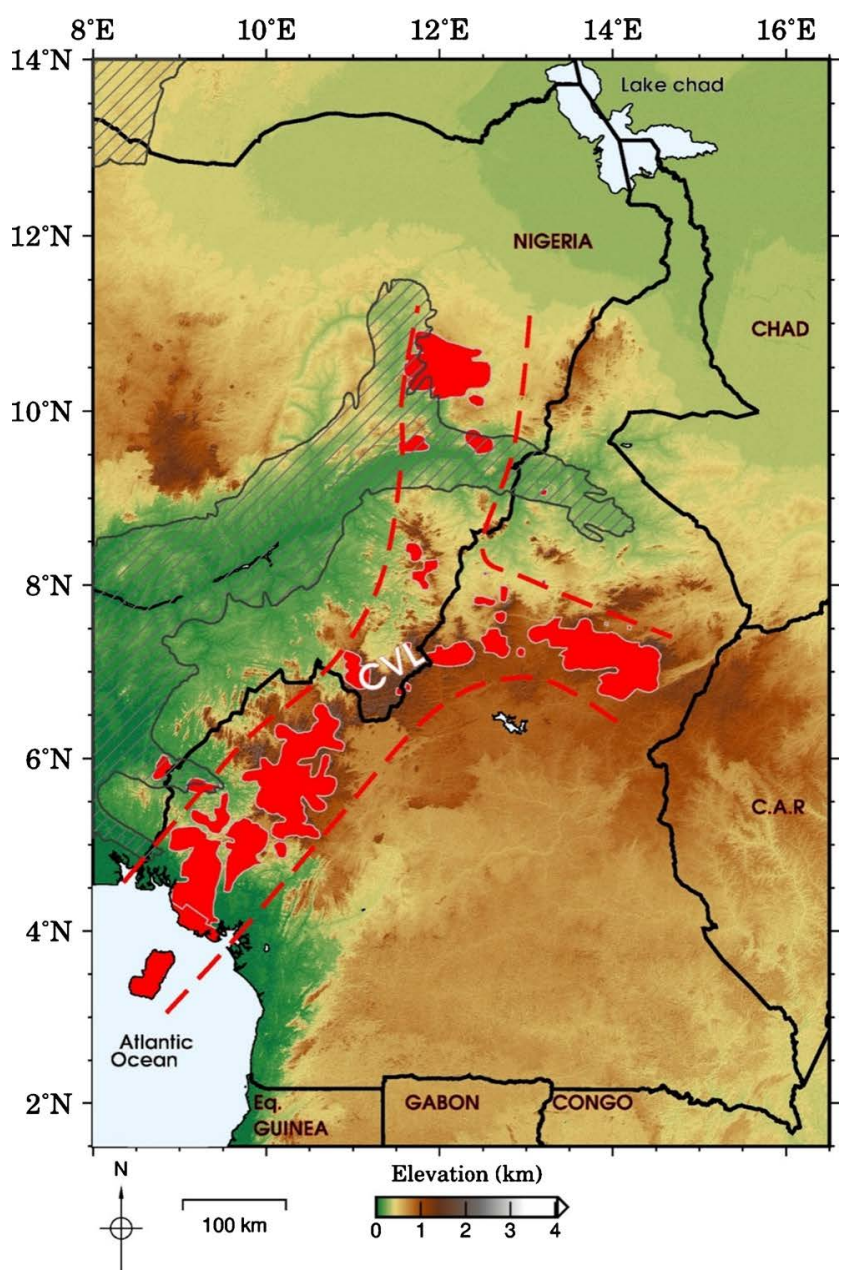

Figure 2. Topography of the study area from ETOPO1 database. 
[35]). The new model EGM2008 has been corrected for the long wavelength $(\geq 300 \mathrm{~km})$ using Gravity Recovery and Climate Experiment (GRACE) satellite data. The model provides earth's external gravitational potential by a spherical harmonic model complete to degree and order 2159, with additional spherical harmonic coefficients extending up to degree 2190 and order to 2159 . This new model provides gravity data with a $5^{\prime} \times 5^{\prime}$ nominal resolution. [36] discussed the EGM2008 model in comparison to local gravity data sets, and demonstrated its usability for regional geophysical modelling. From the free-air gravity anomaly, the Bouguer gravity anomaly (Figure $3(\mathrm{a})$ ) has been calculated.

In this first result, it appears that within the CVL, the strongest positive anomalies are located at the Mt. Cameroon region (until $40 \mathrm{mGal}$ ) while the strongest negative anomalies are located at the central part of the CVL (until-120 $\mathrm{mGal})$. The Bouguer correction was calculated using the ETOPO1 elevation data [34] [36] and by applying the Bouguer correction with a density of $2670 \mathrm{~kg} / \mathrm{m}^{3}$ for the Bouguer slab using GEOSOFT software [36] [37].

Positive Bouguer gravity anomaly in the West part of the chart confirms that crust's thickness beneath Mt. Cameroon region and Benue through is the most prominent of the study region.

This first result is impacted by the deep structure of the crust. Moreover, at regional scale, only major features can be identified on the Bouguer gravity anomaly chart.

To remove the deep crust effect, an isostatic separation of the Bouguer gravity anomaly has been done, with 2.67 as the average value of the density of the crust, $30 \mathrm{Km}$ as the average value of the crust's depth and 0.33 as density contrast over the study area. The result (Figure 3(b)) shows very heavy structures in the South-West part of the continental CVL. The Mt. Cameroon region is seat of the highest Bouguer anomaly along the CVL with a maxima of $62 \mathrm{mGal}$. At the north of that region, another peak of Bouguer anomaly appears around of 58 $\mathrm{mGal}$. On each side of axis formed by these two peaks of positives anomaly, there are negative anomalies: a minima of around $-20 \mathrm{mGal}$ at the West (Rio del ray sedimentary basin) and at the East a minima of around $-17 \mathrm{mGal}$. By moving northward of the CVL, Bouguer anomalies become relatively weak. It appears at the Adamawa plateau a Y shape of positive Bouguer anomaly (around $10 \mathrm{mGal}$ ) which separates three areas of masse defect: $-30 \mathrm{mGal}$ following SW-NE direction, $-20 \mathrm{mGal}$ following SE-NW direction and $-10 \mathrm{mGal}$ Following NW-SE direction.

\subsection{Magnetic}

The magnetic data set used in this study is the global Earth Magnetic Anomaly Grid (EMAG2), which is a compilation from available satellite, airborne and marine magnetic measurements [36] [38]. This model updates the World Digital Magnetic Anomaly Map (WDMAM) [36] [39]. The nominal resolution has been improved from $3 \operatorname{arc} \min (\sim 5 \mathrm{~km})$ to $2 \operatorname{arc} \min (\sim 3 \mathrm{~km})$, and the altitude observation level is 


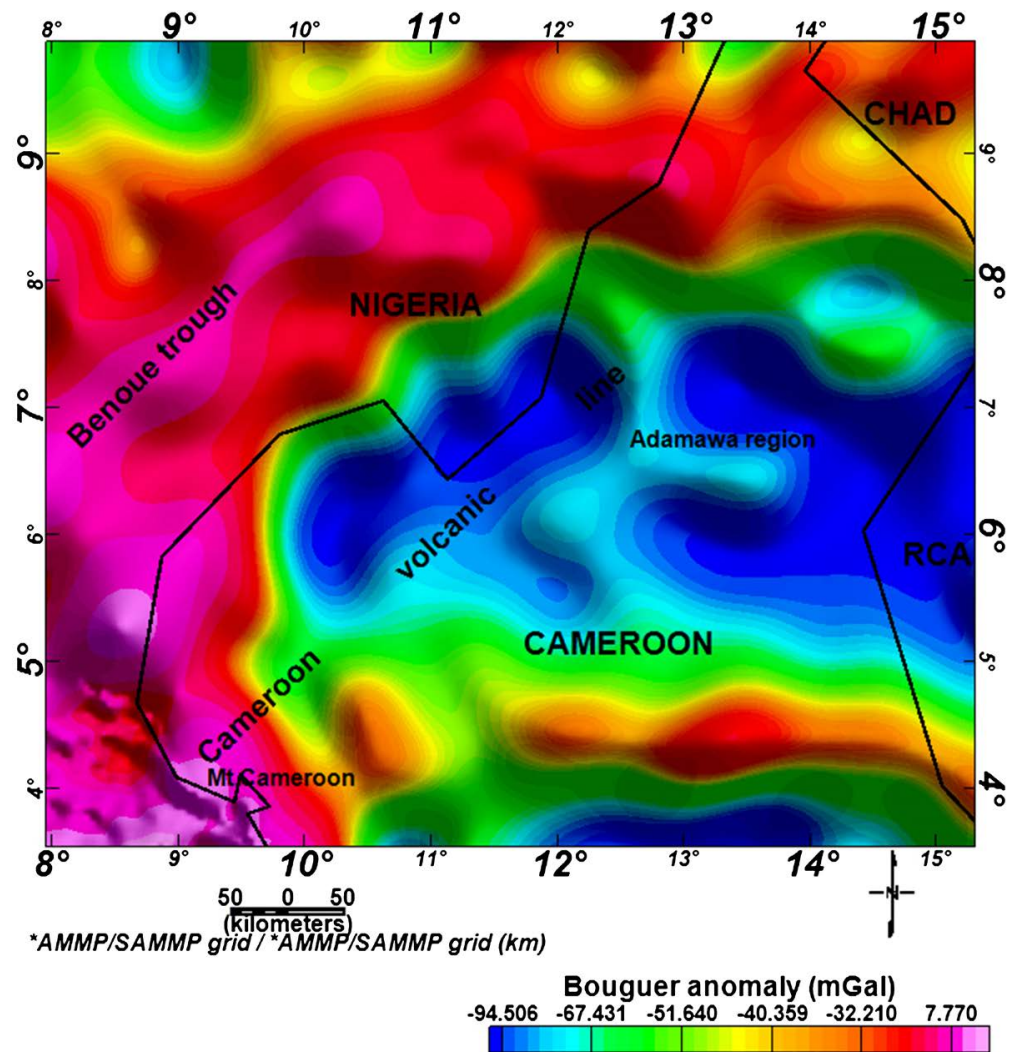

(a)

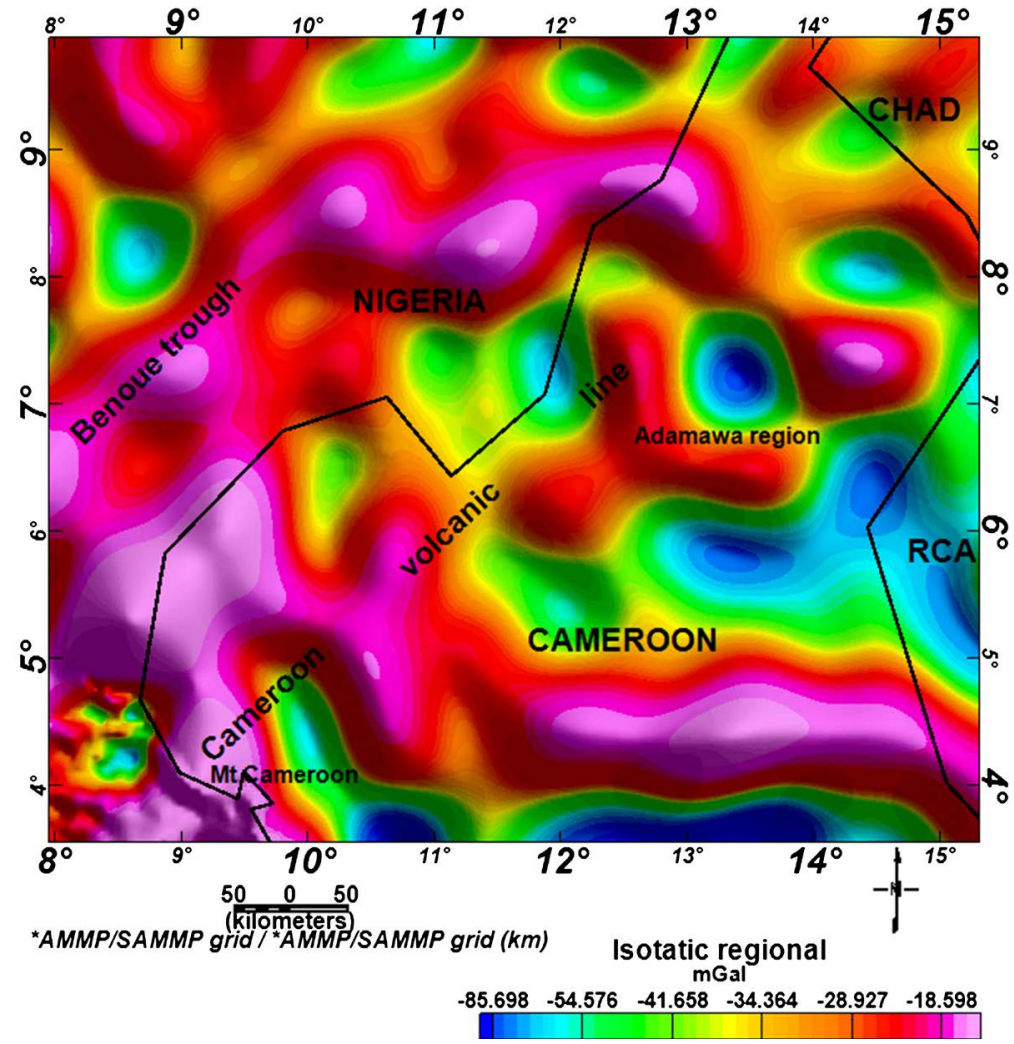

(b)

Figure 3. (a) Bouguer anomaly; (b) Isostatic residual of the Bouguer anomaly. 
decreased from $5 \mathrm{~km}$ to $4 \mathrm{~km}$ above the geoid [36] [38]. For the purpose of this study, these data sets have been gridded to produce $5 \times 5 \mathrm{~km}$ grid (Figure 4 (a)) using the minimum curvature technic. On this grid, it appears that the North part of CVL is the most magnetized, with long wavelength and some relative peaks. In that part, magnetic anomaly values are varying between $20 \mathrm{nT}$ and 120 $\mathrm{nT}$. Inversely, the Southern part of the continental CVL holds a very weak magnetic anomaly. In some area this anomaly is even negative (until $-40 \mathrm{nT}$ ). Magnetic anomaly remains positive around each CVL's mountain, and the Mt. Cameroon region is seat of the most strength anomaly (42 nT). For more precision on the location of magnetic rocks within the studied region, the analytic signal has been gridded. Amplitude $(A)$ of the analytic signal of the total magnetic field $(F)$ was calculated from the three orthogonal derivatives of the field, being defined as the square root of the squared sum of the vertical and horizontal derivatives of the magnetic field [40]:

$$
|\boldsymbol{A}(x, y)|=\left[\left(\frac{\mathrm{d} \boldsymbol{F}}{\mathrm{d} x}\right)^{2}+\left(\frac{\mathrm{d} \boldsymbol{F}}{\mathrm{d} y}\right)^{2}+\left(\frac{\mathrm{d} \boldsymbol{F}}{\mathrm{d} z}\right)^{2}\right]^{\frac{1}{2}}
$$

where $\boldsymbol{A}(x, y)$ is the amplitude of the analytic signal at $(x, y)$, and $\boldsymbol{F}$ is the observed magnetic field at $(x, y)$.

The horizontal derivatives are calculated directly from a total magnetic field grid using a simple $3 \times 3$ filter, while the vertical gradient is calculated using a fast Fourier Transform technique [41].

The result of this operation (Figure 4(b)) shows that main source sets of magnetic anomaly in the CVL are located in the Cameroon South-West region, in the Adamawa plateau region and in the Biu plateau. The result also shows that peaks of total derivative of magnetic anomaly is well discrete and no large, therefore sources are not regional. In the South-West region, Mt. Etinde and Mt. Cameroon are seat of peak of gradient in the range of 3 to $5 \mathrm{nT} / \mathrm{Km}$ corresponding to positive anomalies (the area contains magnetic units). But around this and until Mt. Manengouba, others peaks appear in the range of 3 to 4 $\mathrm{nT} / \mathrm{Km}$ corresponding to negative anomalies. Toward NNW direction after the South-West region, the analytic signal values are almost null: this part of the CVL doesn't contain rocks source of magnetic anomalies. In the Adamawa region, many peaks ( 3 to $6 \mathrm{nT} / \mathrm{Km}$ ) appear along a belt of S-E direction and all correspond to positive magnetic anomalies. Just above this belt, there is a relatively large peak of $5 \mathrm{nT} / \mathrm{Km}$ between two large zones containing none rock source of magnetic anomaly.

Hence, the main magnetic anomaly sources are identified and located on the surface. By using the Euler deconvolution, depth of these sources underground will be gotten.

Euler deconvolution is based on solving Euler's homogeneity Equation (2) [42]: The rate of field change with distance, applied to map gridded data, can be used to estimate the depth and location of a source by solving Euler's Homogeneity 


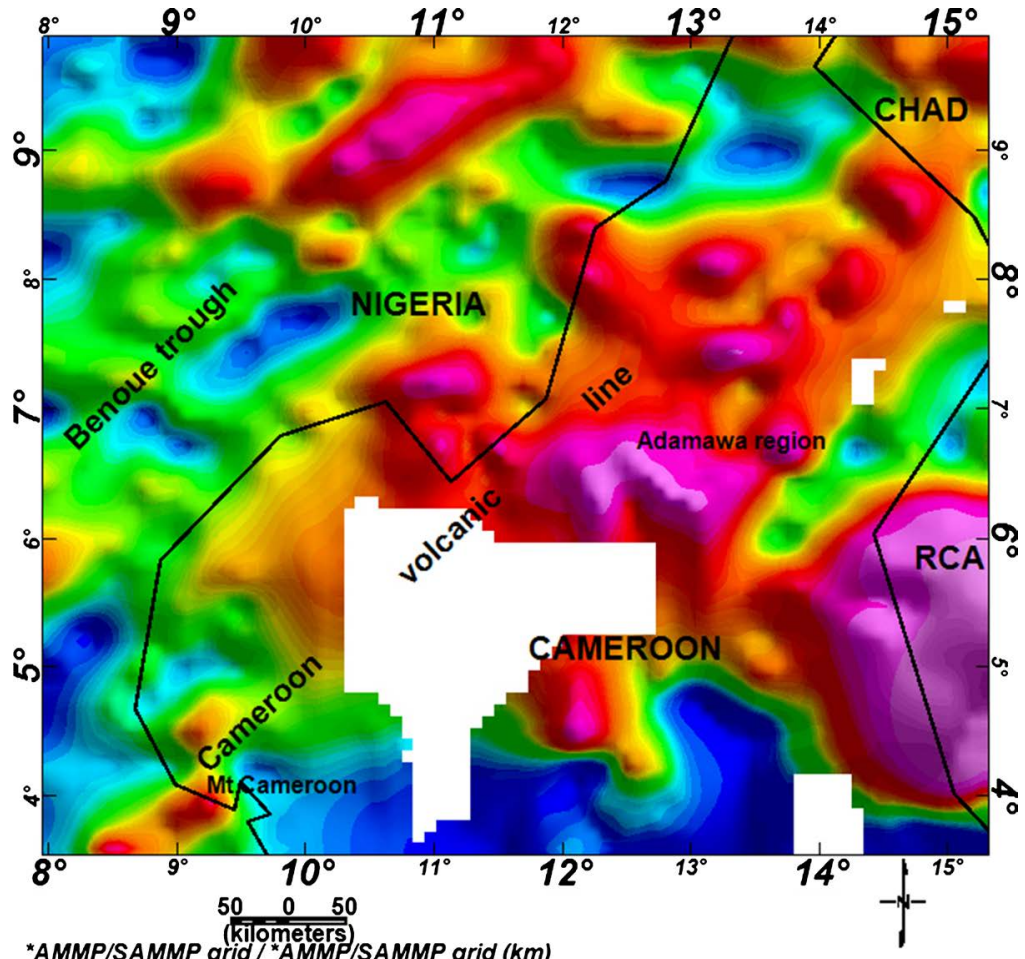

Magnetic anomaly ( $\mathrm{nT}$ )

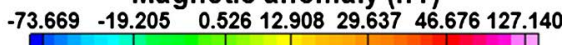

(a)

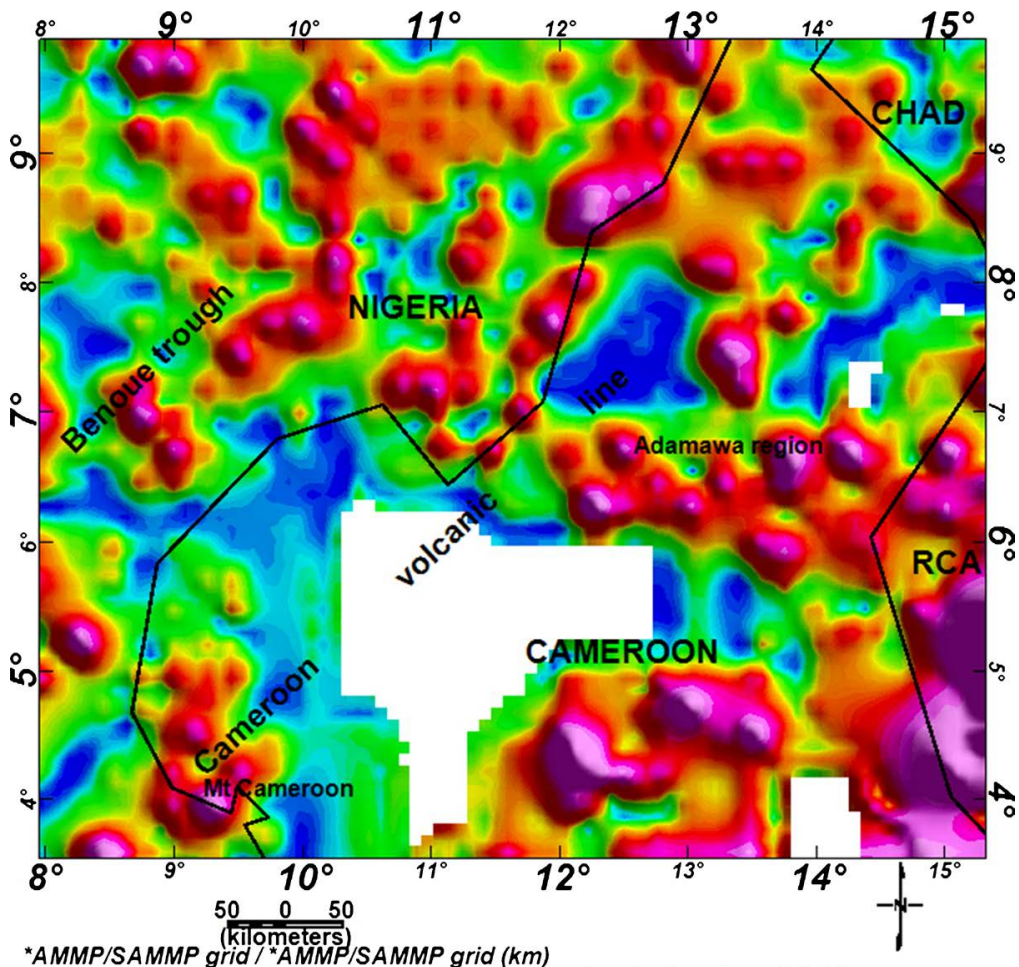

Analytic signal (nT) $0.293 \quad 0.582 \quad 0.8081 .062 \quad 1.3281 .6072 .0383 .083$

(b)

Figure 4. (a) Magnetic anomaly; (b) Analytic signal of the study area. 
Equation which states that:

$$
\left(x-x_{0}\right) \frac{\partial \boldsymbol{F}}{\partial x}+\left(y-y_{0}\right) \frac{\partial \boldsymbol{F}}{\partial y}+\left(z-z_{0}\right) \frac{\partial \boldsymbol{F}}{\partial z}=N(\boldsymbol{B}-\boldsymbol{F})
$$

where $x_{0}, y_{0}$ and $z_{0}$ are the source locations whose magnetic field is $F$, measured at $x, y$ and $z, B$ is the regional value of the total magnetic field, $N$ is the Structural Index (SI) which characterizes the source geometry. In this study, values 2 and 3 have been assigned to $\mathrm{N}$ for the detection of pipe and spherical or near-shaped bodies. The Euler deconvolution operation has been realized for 10 $\mathrm{km}$ of depth and results were plotted (Figure 5). This result shows that Euler's solutions coincide with peaks of analytic signal confirming the presence of bodies' source of anomalies into the window chose $(10 \mathrm{Km})$. In the Adamawa region, all solutions correspond to sources of positive anomalies, but in the South-West region, some solutions correspond to sources of both positive and negative anomalies.

\subsection{Modeling and Discussion}

The above presentation of the gravity and magnetic anomalies reveals that two main areas of the CVL display simultaneously remarkable gravity and magnetic anomalies: South-West and Adamawa regions. Based on the Euler's solutions display, it has been described four profiles, crossing axes of main sources of gravity anomalies in these two regions (Figure 6). Along these four profiles P1, P2, P3 and P4, 2D1/2 models have been constructed to get a quantitative estimation

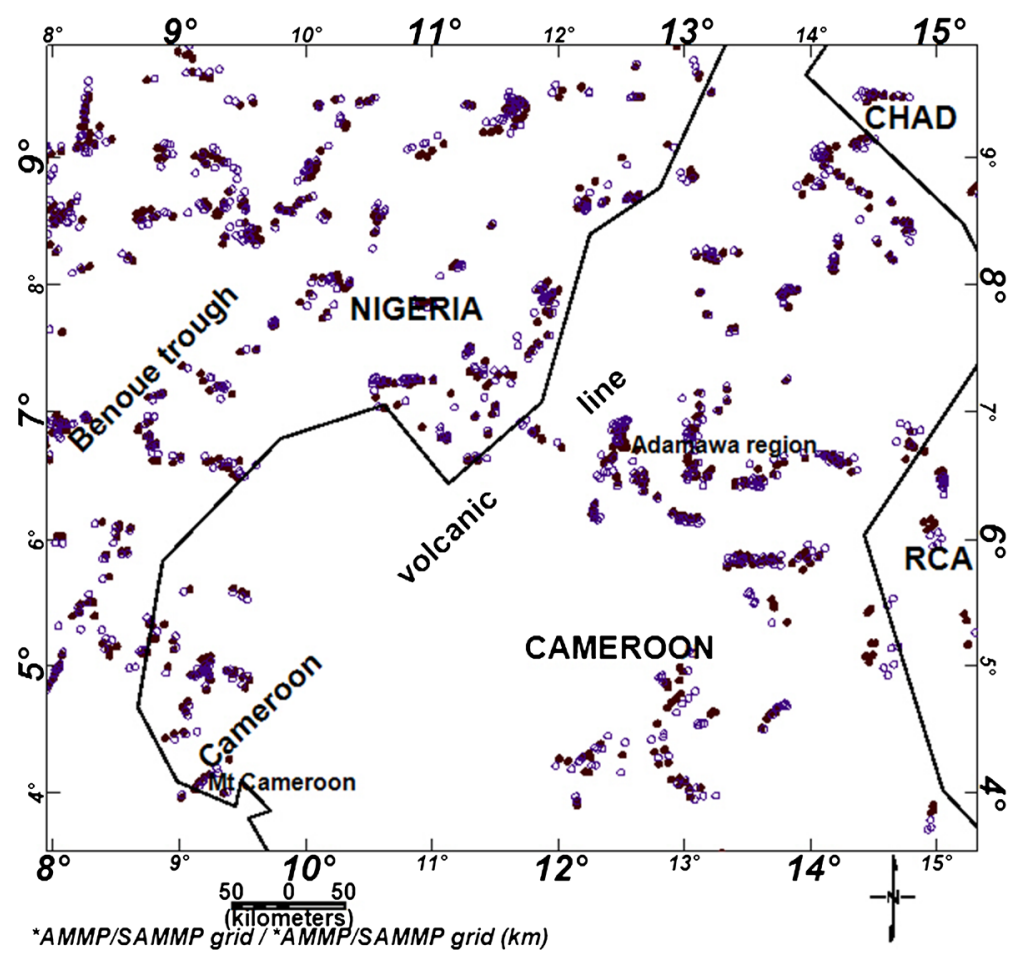

Figure 5. Euler's solutions: full circle for pipe shape (index 2) and empty circle for spherical shape (index 3). 


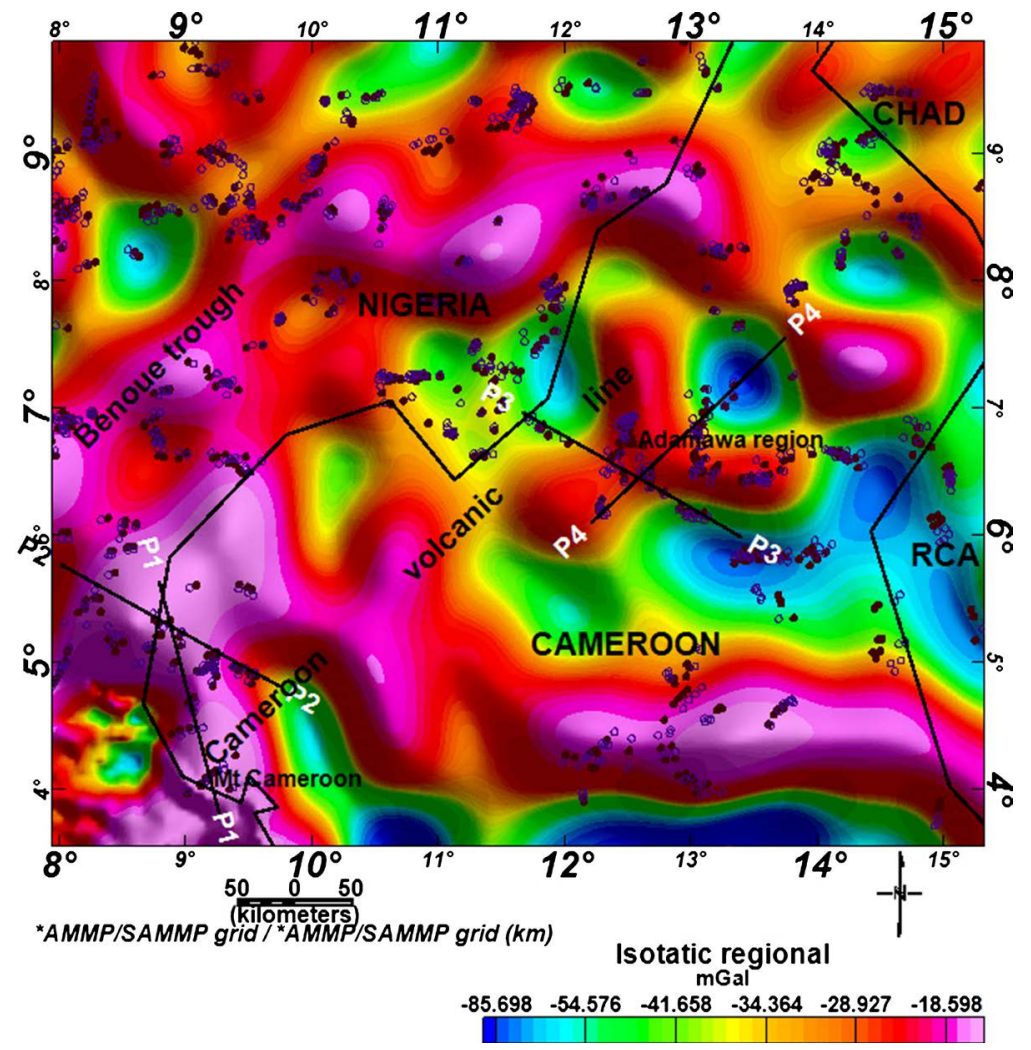

Figure 6. Superposition of Euler's solutions on Bouguer Isostatic residual and profiles P1, P2, P3 and P4 layout.

after the qualitative work previously done.

A major problem in constructing geological models is the lack of subsurface constraints (seismic reflection or refraction, density information and drill hole data...). Given these obstacles, only general models can be derived showing approximate geometries and thicknesses of the source bodies of any given anomalies. To conceive an acceptable geological model, a density value for each modeled lithological unit is required. Rock densities were estimated from average values measured from rock samples worldwide [43] as no density measurements were available from rock samples, seismic velocity measurements or drill holes. The final models were obtained through a trial and error process until the calculated gravity values matched the observed gravity values using geologic and magnetic constraints.

The gravity models show that rocks within the studied areas are very diverse, with densities ranging between $2.57 \mathrm{~g} / \mathrm{cc}$ and $2.87 \mathrm{~g} / \mathrm{cc}$. Models also show that the majority of source rocks with gravity anomaly signal within studied regions are large and deep, except along the profile P1 (Figure 7: some bodies are relatively small and located close to the surface) the Mt. Cameroon region. Globally, bodies located within the South-West region are denser than rocks within the Adamawa region.

The model along P1 (Figure 7) shows five main bodies as a source of gravity anomalies observed in the region. The body (1) is characterized by $2.84 \mathrm{~g} / \mathrm{cc}$ 


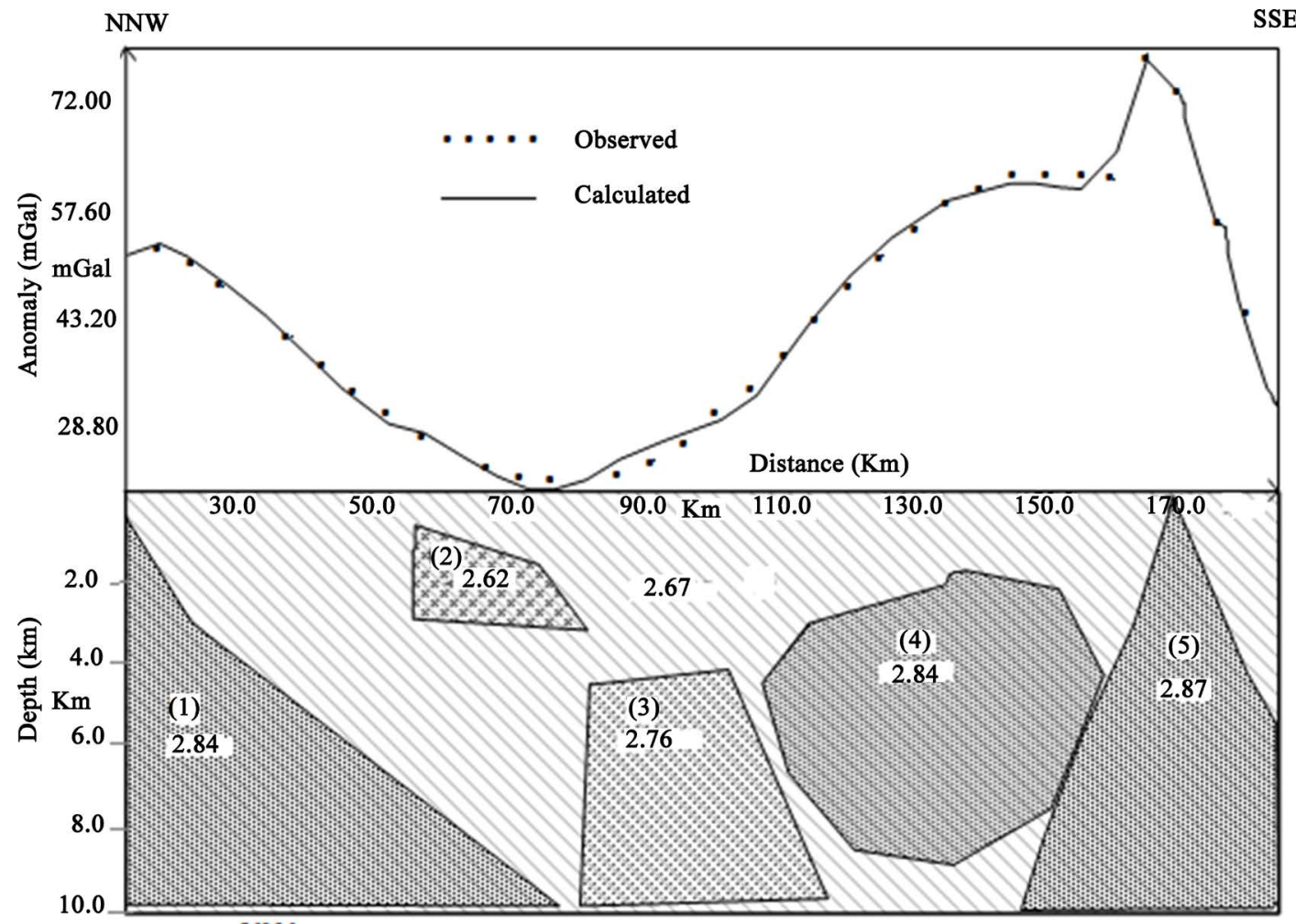

Figure 7. Two and one-half dimensional gravity model along profile P1 across the South-west part of the continental CVL. The numbered bodies and their densities in $\mathrm{mg} / \mathrm{cm}^{3}$ are: (1) Nigerian granitic complexes 213 - $141 \mathrm{Ma}$ (2.84); (2) sediment rock (2.62); (3) heavy basalt (2.76); (4) crystallized source material (2.84); (5) metavolcanic rock (2.87).

with a soft magnetic anomaly $(7-8 \mathrm{nT})$, and has been modeled as crystallized source material located between 3 and $10 \mathrm{Km}$ of depth. The body (2) which is less large and less dense $(2.62 \mathrm{~g} / \mathrm{cc})$, has been modeled as Precambrian granitic batholith's fragment, located near the surface and might be linked to the tectonic event responsible for the separation of African and Southern American plates. Body (3) has been modeled as a very heavy basalt of $2.76 \mathrm{~g} / \mathrm{cc}$ located between 5 $\mathrm{km}$ and $10 \mathrm{~km}$ while body (4) has been modeled as a spherical crystallized source material, certainly from the same origin as the body (1). The body (5) which is the densest (2.87) is source of a substantial magnetic anomaly (about $50 \mathrm{nT}$ ); it has been located under the Mt. Cameroon and has been modeled as a pyramidal form of Precambrian metavolcanics. These models show that South-West's basement is mainly made up of basaltic and other metavolcanic bodies. That result is similar to that of [44]. According to him the basement of this region is crystalline and marked by many huge volcanic mountains, as a result of important volcanic eruptions.

The model into the South-West region (Figure 8) consists of two bodies, sources of anomalies. The denser $(2.81 \mathrm{~g} / \mathrm{cc})$ under the NW of P2 is logically the same body as the body (1) under the NNW of P1. It has a soft magnetic anomaly between 7 and $-8 \mathrm{nT}$ and has been modeled as crystallized source material, which takes place from near the surface up to $10 \mathrm{~km}$ of depth. Next to this body 


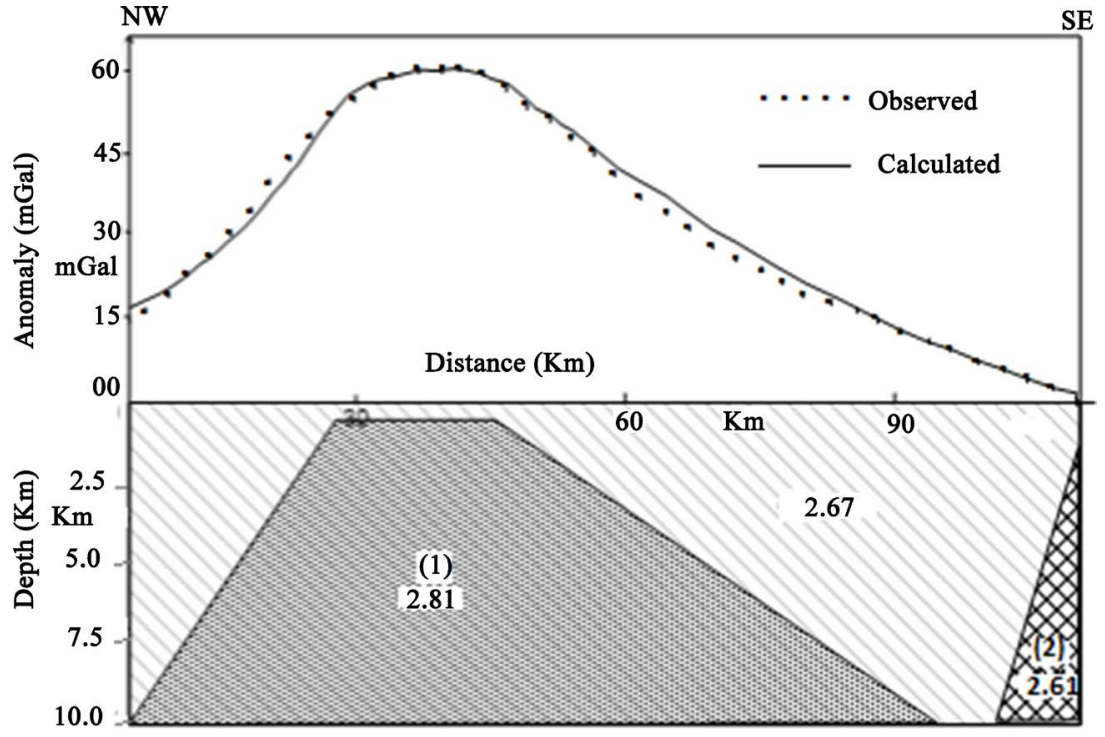

Figure 8. Two and one-half dimensional gravity model along profile P2 across the South-west part of the continental CVL. The numbered bodies and their densities in $\mathrm{mg} / \mathrm{cm}^{3}$ are: (1) Nigerian granitic complexes 213-141 Ma (2.81); (2) Sediment complex (2.61).

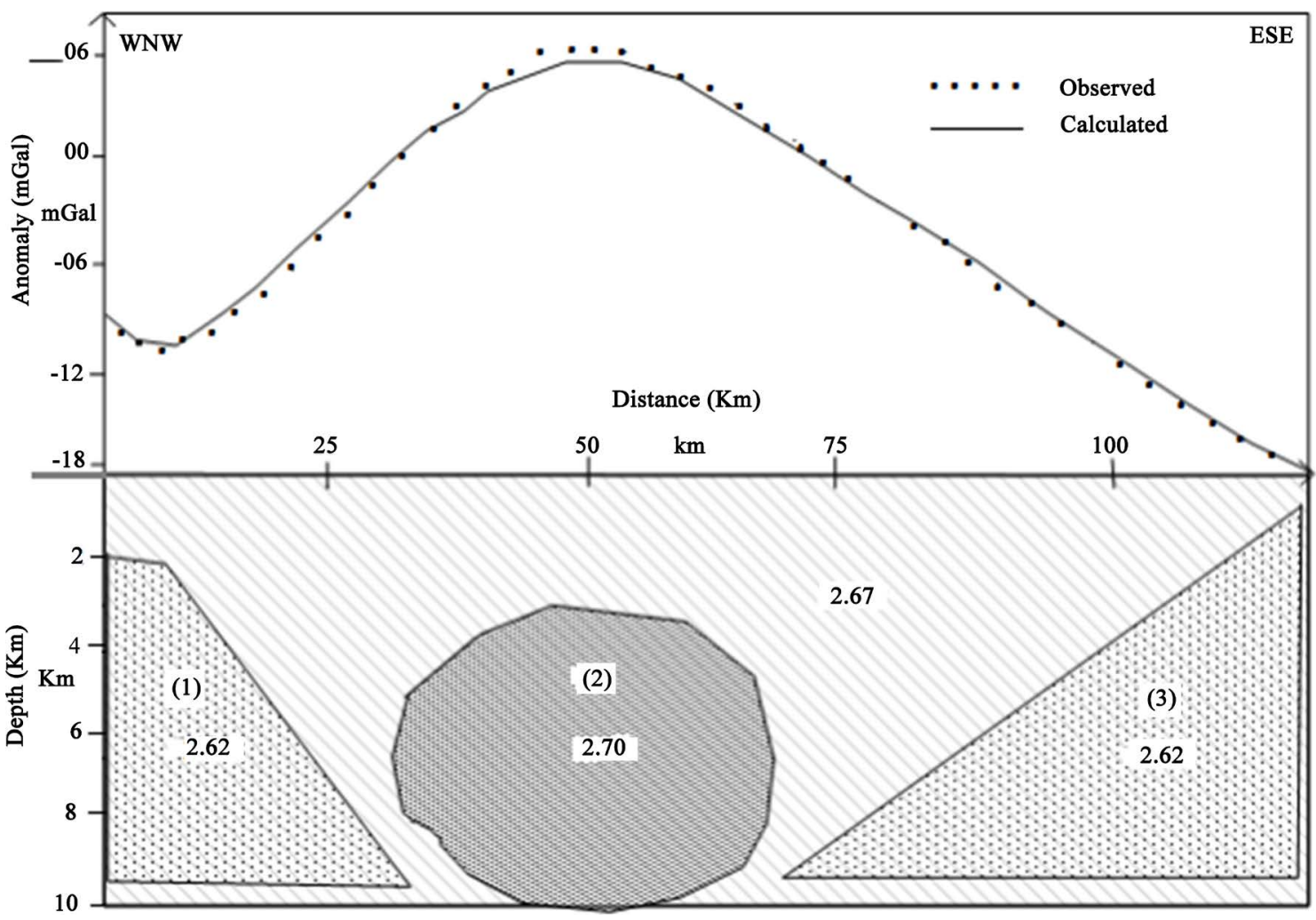

Figure 9. Two and one-half dimensional gravity model along profile P3 across the South part of the Adamawa plateau. The numbered bodies and their densities in $\mathrm{mg} / \mathrm{cm}^{3}$ are: (1) and (3) Precambrian granitic batholith (2.62) and (2) Precambrian basement rocks (2.70).

along P2, there is a mass defect $(2.61 \mathrm{~g} / \mathrm{cc})$, the body (2) which is a source of magnetic anomalies in order of $5 \mathrm{nT}$ and that has been modeled as a sediment complex. 
The model along P3 located beneath the Adamawa region (Figure 9) consists of three bodies, sources of strong magnetic anomaly (from 70 to $115 \mathrm{nT}$ ). Bodies (1) and (3) are sediments source of masse defect $(2.62 \mathrm{~g} / \mathrm{cc})$ with about $75 \mathrm{nT}$ of magnetic anomaly have been modeled as Precambrian granitic batholith which takes place from around $2 \mathrm{Km}$ to $10 \mathrm{Km}$ of depth and separate by the body (2) modeled as basaltic because of its density $(2.69 \mathrm{~g} / \mathrm{cc})$ and its magnetic anomaly of about $115 \mathrm{nT}$.

Under P4, the model (Figure 10) shows also three body sources of anomalies. The body (1) located between $4.5 \mathrm{Km}$ and $10 \mathrm{Km}$, is source of soft gravity anomaly ( $2.68 \mathrm{~g} / \mathrm{cc}$ ) and strongly magnetized (up to $115 \mathrm{nT}$ of magnetic anomaly) and has been modeled as basaltic unit. It is certainly a prolongation of body (1) into the model C. The second body (2) is less magnetized than the first (60 - 80 $\mathrm{nT}$ of magnetic anomaly) but denser $(2.70 \mathrm{~g} / \mathrm{cc})$ and has been modeled as a shallow unit of basalt (from $2 \mathrm{Km}$ ). Contrarily to previous bodies, the body (3) under NE front of P4 is a mass defect of $2.58 \mathrm{~g} / \mathrm{cc}$ and without magnetic anomaly. It has been modeled as pyroclastic/rhyolite unite that extends from 3 to 10 $\mathrm{Km}$ of depth. Hence, the basement of the Adamawa plateau is modeled into the first 10 kilometers as pyroclastic/rhyolite and Precambrian granitic batholith units intruded by basaltic rocks. This result is in agreement with [2] [15]. According to these authors, the Ngaoundere Plateau, consists of alkaline basalts and basanites capped by trachytes and phonolitic flows.

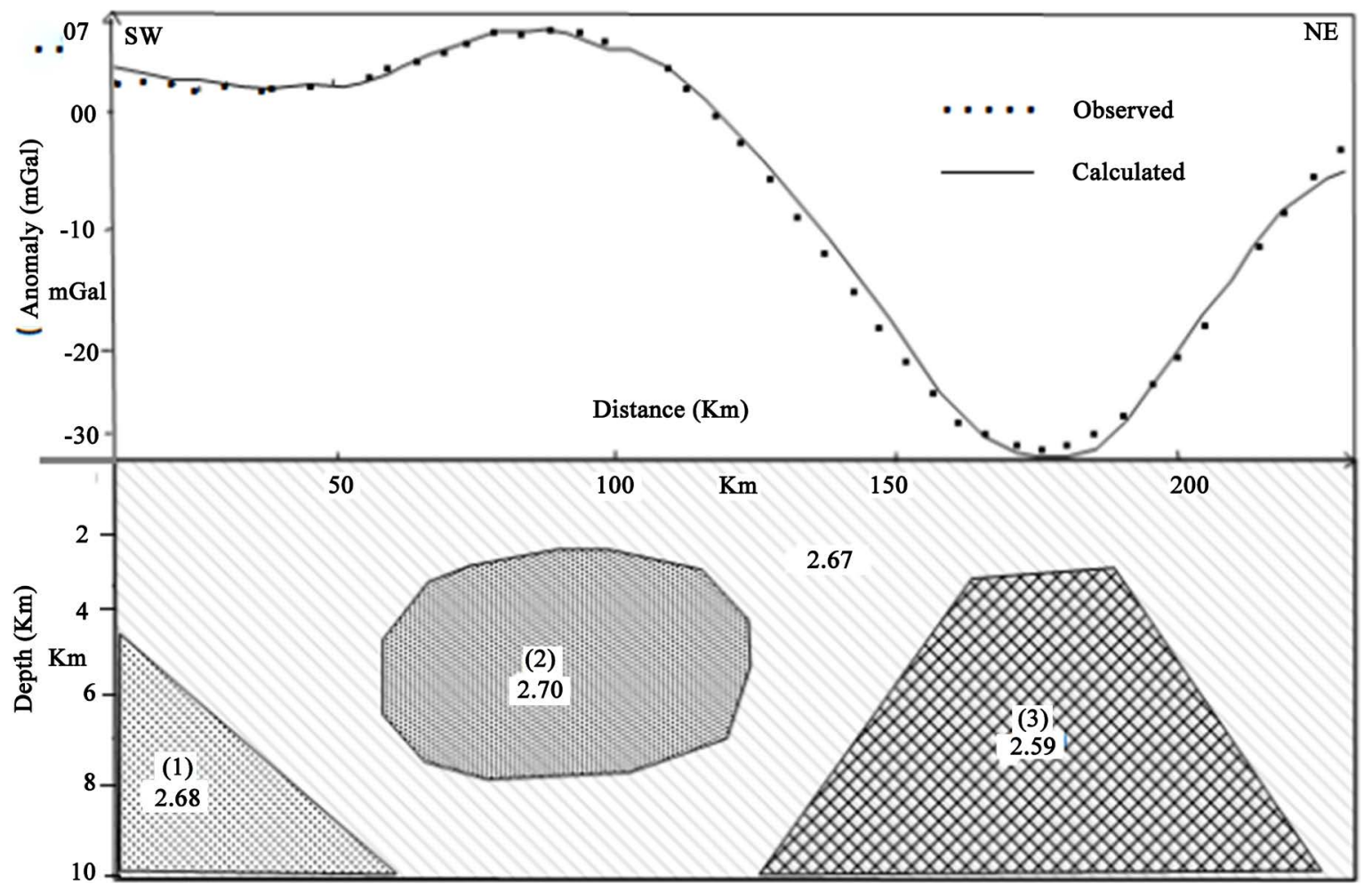

Figure 10. Two and one-half dimensional gravity model along profile P4 across the Adamawa plateau. The numbered bodies and their densities in $\mathrm{mg} / \mathrm{cm}^{3}$ are: (1) acid volcanic flows (2.59); (2) Precambrian basement rocks (2.70) and (3) basaltic body (2.68). 
The most recent volcanism in this area consists of cinder cones aligned in a WNW-ESE direction, sometimes producing small lava flows.

These old bodies (crystalline source rock, Precambrian granitic batholith and very heavy basalt) have endured during long age strong pressure and temperature, which would probably lead to the formation of rare ores. Also, with a favorable hydrothermal system, the study region would hold many ore fields like graphite (which occurs in eruptive and hot metamorphic rocks); sulfur (which upholster side around the volcanic steam); copper (taking place in basic eruptive rock); another ore $\left(\mathrm{FeTiO}_{3},(\mathrm{Mn}, \mathrm{Fe})_{2} \mathrm{O}_{3},(\mathrm{Mn}, \mathrm{Fe})_{2} \mathrm{O}_{3}\right.$, olivines $\left.(\mathrm{Mg}, \mathrm{Fe})_{2} \mathrm{SiO}_{4}\right)$ which also take place into eruptive rocks and which explain through their presence, the high magnetism in the Adamawa plateau and Mt. Cameroon regions.

\section{Conclusions}

This work aimed to study the Cameroon Volcanic Line from gravity and magnetic data, in order to explore potentials ore deposits across this area. To get the main aim of this study, isostatic separation has been applied to gravity data to obtain the isostatic residual. Then the analytic signal and Euler deconvolution have been applied to magnetic data as it was needed on one hand to identify and locate magnetic sources on the surface and on the other hand to get an idea about depths of these sources underground. To end, Euler's solutions and isostatic residual have been crossed in order to choose good profile locations and construct different models.

The study has revealed many particularities. The Bouguer gravity anomalies transformed into isostatic residual gravity anomalies showed that the study area can be split in two main regions: the South-West part characterized by anomalies of great wavelength with strong intensity and the Adamawa region part, overall characterized by a large mass defect crossed by denser $\mathrm{Y}$ bodies shaped forward NE direction. Contrary to gravity signal, magnetic anomaly wavelength is globally longer and stronger in the Adamawa region than in the South-West, except at Mt. Cameroon and Mt. Etinde which are particular seats of strong magnetism. The analytic signal has confirmed that these two mountains and the Adamawa region were seats of magnetic bodies. The Euler deconvolution revealed that sources of these magnetic anomalies were potentially located into the first $10 \mathrm{~km}$ except for the strong magnetic body over the Adamawa, which must be located deeper. The four gravity models were built along four profiles chosen following the Euler solutions layout and the feature of gravity anomalies, indicated that the observed anomalies are caused by a series of both low and high density bodies compared to the country rock (granite, $2.67 \mathrm{~g} / \mathrm{cc}$ ) within South-West and Adamawa region. Despite the lack of subsurface constraints in CVL, calculated bodies located between 1 and $10 \mathrm{~km}$ have been interpreted as old rocks (crystalline source rock, Precambrian granitic batholith and very heavy basalt) then as potential reservoirs of rare ores. In addition, volcanic rocks modeled have constituted potential reserves of other ores like graphite, 
sulfur, copper, iron.

\section{Acknowledgements}

Authors are very grateful to Cameroon Institute for Geological and Mining Research (IRGM) for providing a framework for this study. We also thank Joanna Cheng, Editorial Assistant and reviewers for handling and constructive comments on the manuscript.

\section{Conflicts of Interest}

The authors declare no conflicts of interest regarding the publication of this paper.

\section{References}

[1] Dewey, J.F. and Burke, K. (1974) Hot Spots and Continental Break-Up: Implications for Collisional Orogeny. Geology, 2, 57-60. https://doi.org/10.1130/0091-7613(1974)2<57:HSACBI >2.0.CO;2

[2] Fitton, J.G. (1987) The Cameroon Line, West Africa: A Comparison between Oceanic and Continental Alkaline Volcanism. In: Fitton, J.G. and Upton, B.G.J., Eds., Alkaline Igneous Rocks, 30, Geological Society London Special Publications, London, 273-291. https://doi.org/10.1144/GSL.SP.1987.030.01.13

[3] Freeth, S.J. (1979) Deformation of the African Plate as a Consequence of Membrane Stress Domains Generated by Post-Jurassic Drift. Earth and Planetary Science Letters, 45, 93-104. https://doi.org/10.1016/0012-821X(79)90111-0

[4] Burke, K. (2001) Origin of the Cameroon Line of Volcano-Capped Swells. The Journal of Geology, 109, 349-362. https://doi.org/10.1086/319977

[5] King, S.D. and Anderson, D.L. (1995) An Alternative Mechanism of Flood Basalt Formation. Earth and Planetary Science Letters, 136, 269-279.

https://doi.org/10.1016/0012-821X(95)00205-Q

[6] Meyers, J.B., Rosendahl, B.R., Harrison, C.G. and Ding, Z.D. (1998) Deep-Imaging Seismic and Gravity Results from the Offshore Cameroon Volcanic Line, and Speculation of African Hotlines. Tectonophysics, 284, 31-63. https://doi.org/10.1016/S0040-1951(97)00173-X

[7] Reusch, A.M., Nyblade, A.A., Wiens, D.A., Shore, P.J., Ateba, B., Tabod, C.T. and Nnange, J.M. (2010) Upper Mantle Structure beneath Cameroon from Body Wave Tomography and the Origin of the Cameroon Volcanic Line. Geochemistry, Geophysics, Geosystems, 11. https://doi.org/10.1029/2010GC003200

[8] Halliday, A.N., Dicken, A.P., Fallick, A.E. and Fitton, J.D. (1988) Mantle Dynamics: $\mathrm{A} \mathrm{Nd}, \mathrm{Sr}, \mathrm{Pb}$ and Os Isotope Study of the Cameroon Line Volcanic Chain. Journal of Petrology, 29, 181-211. https://doi.org/10.1093/petrology/29.1.181

[9] Ngako, V., Njonfang, E., Aka, F.T., Affaton, P. and Nnange, J.M. (2006) The North-South Paleozoic to Quaternary Trend of Alkaline Magmatism from Niger-Nigeria to Cameroon: Complex Interaction between Hotspots and Precambrian Faults. Journal of African Earth Sciences, 45, 241-256.

https://doi.org/10.1016/j.jafrearsci.2006.03.003

[10] Fairhead, J.D. (1988) Mesozoic Plate Tectonic Reconstructions of the Central South Atlantic Ocean: The Role of the West and Central African Rift System. Tectonophysics, 155, 181-191. https://doi.org/10.1016/0040-1951(88)90265-X 
[11] Fitton, J.G. and Dunlop, H.M. (1985) The Cameroon Line, West Africa and Its Bearing on the Origin of Oceanic and Continental Alkali Basalts. Earth and Planetary Science Letters, 72, 23-38. https://doi.org/10.1016/0012-821X(85)90114-1

[12] Deruelle, B., Ngounouno, I. and Demaiffe, D. (2007) The Cameroon Hot Line (CHL): A Unique Example of Active Alkaline Intraplate Structure in Both Oceanic and Continental Lithospheres. Comptes Rendus Geoscience, 339, 589-600. https://doi.org/10.1016/j.crte.2007.07.007

[13] Marzoli, A., Piccirillo, E.M., Renne, P.R., Bellieni, G., Iacumin, M., Nyobe, J.B. and Tongwa, A.T. (2000) The Cameroon Volcanic Line Revisited: Petrogenesis of Continental Basaltic Magmas from Lithospheric and Asthenospheric Mantle Sources. Journal of Petrology, 41, 87-109. https://doi.org/10.1093/petrology/41.1.87

[14] Ngounouno, I., Deruelle, B. and Demaiffe, D. (2000) Petrology of the Bimodal Cenozoic Volcanism of the Kapsiki Plateau (Northernmost Cameroon, Central Africa). Journal of Volcanology and Geothermal Research, 102, 21-44. https://doi.org/10.1016/S0377-0273(00)00180-3

[15] Nono, A., Deruelle, B., Demaiffe, D. and Kambou, C.R. (1994) Tchabal Nganha Volcano in Adamawa (Cameroon): Petrology of Continental Lava Series. Journal of Volcanology and Geothermal Research, 60, 147-177. https://doi.org/10.1016/0377-0273(94)90066-3

[16] Rankenburg, K., Lassister, J.C. and Brey, G. (2005) The Role of Continental Crust and Lithospheric Mantle in the Genesis of Cameroon Volcanic Line Lavas: Constraints from Isotopic Variations in Lavas and Megacrysts from the Biu and Jos Plateau. Journal of Petrology, 46, 169-190. https://doi.org/10.1093/petrology/egh067

[17] Sato, H., Aramaki, S., Kusakabe, M., Hirabayashi, J.I., Sano, Y., Nojiri, Y. and Tchoua, F.M. (1990) Geochemical Difference of Basalts between Polygenetic and Monogenetic Volcanoes in the Central Part of the Cameroon Volcanic Line. Geochemical Journal, 24, 357-370. https://doi.org/10.2343/geochemj.24.357

[18] Nkouathio, D.G., KagouDongmo, A., Bardintzeff, J.M., Wandji, P., Bellon, H. and Pouclet, A. (2008) Evolution of Volcanism in Graben and Horst along the Cenozoic Cameroon Line (Africa): Implication for Tectonic Evolution and Mantle Source Composition. Mineralogy and Petrology, 94, 287-303. https://doi.org/10.1007/s00710-008-0018-1

[19] Nkoumbou, C., Deruelle, B. and Velde, D. (1995) Petrology of Mt Etindenephelinites Series. Journal of Petrology, 36, 373-395.

https://doi.org/10.1093/petrology/36.2.373

[20] Geze, B. (1943) Géographie physique et géologie du Cameroun occidental, 17. Mem. Mus. Natl. Hist. Nat., Paris, Nouv. Ser, 1-272.

[21] Fitton, J.G., Kilburn, C.R.J., Thirlwall, M.F. and Hughes, D.J. (1983) 1982 Eruption of Mount Cameroon, West Africa. Nature, 306, 327.

https://doi.org/10.1038/306327a0

[22] Suh, C.E., Sparks, R.S.J., Fitton, J.G., Ayonghe, S.N., Annen, C., Nana, R. and Luckman, A. (2003) The 1999 and 2000 Eruptions of Mount Cameroon: Eruption Behaviour and Petrochemistry of Lava. Bulletin of Volcanology, 65, 267-281. https://doi.org/10.1007/s00445-002-0257-7

[23] Suh, C.E., Luhr, J.F. and Njome, M.S. (2008) Olivine-Hosted Glass Inclusions from Scoriae Erupted in 1954-2000 at Mount Cameroon Volcano, West Africa. Journal of Volcanology and Geothermal Research, 169, 1-33. https://doi.org/10.1016/j.jvolgeores.2007.07.004

[24] Yokoyama, T., Aka, F.T., Kusakabe, M. and Nakamura, E. (2007) Plume-Lithosphere 
Interaction beneath Mt. Cameroon Volcano, West Africa: Constraints from 238U-230Th-226Ra and Sr-Nd-Pb Isotope Systematics. Geochimica et Cosmochimica Acta, 71, 1835-1854. https://doi.org/10.1016/j.gca.2007.01.010

[25] KagouDongmo, A., Nkouathio, D., Pouclet, A., Bardintzeff, J.-M., Wandji, P., Nono, A. and Guillou, H. (2010) The Discovery of Late Quaternary Basalt on Mount Bambouto: Implications for Recent Widespread Volcanic Activity in the Southern Cameroon Line. Journal of African Earth Sciences, 57, 96-108.

https://doi.org/10.1016/j.jafrearsci.2009.07.015

[26] Njilah, I.K., Ajonina, H.N., Kamgang, K.V. and Tchindjang, M. (2004) K-Ar Ages, Mineralogy, Major and Trace Element Geochemistry of the Tertiary-Quaternary Lavas from the ndu Volcanic Ridge NW Cameroon. African Journal of Science and Technology, 5, 47-56. https://doi.org/10.4314/ajst.v5i1.15318

[27] Njilah, I., Temdjim, R., Richard, C., Ghogomu, N., Tchuitchou, R. and Ajonina, H. (2007) Geochemistry of Tertiary-Quaternary Lavas of Mt. Oku Northwest Cameroon. Revista Facultad de Ingenieria, 40, 59-75.

[28] Kamgang, P., Njonfang, E., Nono, A., Gountie, D.M. and Tchoua, F. (2010) Petrogenesis of a Silicic Magma System: Geochemical Evidence from Bamenda Mountains, NW Cameroon, Cameroon Volcanic Line. Journal of African Earth Sciences, 58, 285-304. https://doi.org/10.1016/j.jafrearsci.2010.03.008

[29] Tchouankoue, J.P., Wambo, N.A.S., Dongmo, A.K. and Wörner, G. (2012) Petrology, Geochemistry, and Geodynamic Implications of Basaltic Dyke Swarms from the Southern Continental Part of the Cameroon Volcanic Line, Central Africa. The Open Geology Journal, 6, 72-84. https://doi.org/10.2174/1874262901206010072

[30] Coulon, C., Vidal, P., Dupuy, C., Baudin, P., Popoff, M., Maluski, H. and Hermitte, D. (1996) The Mesozoic to Early Cenozoic Magmatism of the Benue Trough (Nigeria); Geochemical Evidence for the Involvement of the St Helena Plume. Journal of Petrology, 37, 1341-1358. https://doi.org/10.1093/petrology/37.6.1341

[31] Wilson, M. and Guiraud, R. (1992) Magmatism and Rifting in Western and Central Africa from Late Jurassic to Recent Times. Tectonophysics, 213, 203-225. https://doi.org/10.1016/0040-1951(92)90259-9

[32] Lasserre, M. (1978) Mise au point sur les granitoïdes dits "ultimes" du Cameroun. Gisements, pétrographie et géochronologie. Bulletin Bureau Recherches Géologiques Minieres. Section 4: Géologie Générale, 2, 143-159.

[33] Aka, F.T., Nagao, K., Kusakabe, M., Sumino, H., Tanyileke, G., Ateba, B. and Hell, J. (2004) Symmetrical Helium Isotope Distribution on the Cameroon Volcanic Line, West Africa. Chemical Geology, 203, 205-223. https://doi.org/10.1016/j.chemgeo.2003.10.003

[34] Amante, C. and Eakins, B.W. (2008) ETOPO1 1 Arc-Minute Global Relief Model: Procedures, Data Sources and Analysis. National Geophysical Data Center, NESDIS, NOAA, U.S. Department of Commerce, Boulder.

[35] Pavlis, N.K., Holmes, S.A., Kenyon, S.C. and Factor, J.K. (2012) The Development and Evaluation of the Earth Gravitational Model 2008 (EGM2008). Journal of Geophysical Research: Solid Earth, 117, B04406. https://doi.org/10.1029/2011JB008916

[36] Eyike, A., Werner, S.C., Ebbing, J. and Dicoum, E.M. (2010) On the Use of Global Potential Field Models for Regional Interpretation of the West and Central African Rift System. Tectonophysics, 492, 25-39. https://doi.org/10.1016/j.tecto.2010.04.026

[37] Acellaration Gravity (2002) Gravity Data Processing System for Oasis Montaj TM. Geosoft. 
[38] Maus, S., Barckhausen, U., Berkenbosch, H., Bournas N., Brozena J., Childers, V., Dostaler, F., Fairhead, J.D., Finn, C., von Frese, R.R.B., Gaina, C., Golynsky, S., Kucks, R., Lühr, H., Milligan, P., Mogren, S., Müller, D., Olesen O., Pilkington, M., Saltus, R., Schreckenberger, B., Thébault, E. and CaratoriTontini, F. (2009) EMAG2: A 2-arc-minute Resolution Earth Magnetic Anomaly Grid Compiled from Satellite, Airborne and Marine Magnetic Measurements. Geochemistry, Geophysics, Geosystems, 10, Q08005. https://doi.org/10.1029/2009GC002471

[39] Korhonen, J., Fairhead, J.D., Hamoudi, M., Hemant, K., Lesur, V., Mandea, M., Maus, S., Peruker, M., Ravat, D., Sazonova, T. and Thebault, E. (2007) World Digital Magnetic Anomaly Map, CCGM-CGMW/UNESCO, 1:50000 000, 1 Sheet and 1 DVD (and the Rest Alphabetically).

[40] Roest, W.R., Verhoef, J. and Pilkington, M. (1992) Magnetic Interpretation Using the 3-D Analytic Signal. Geophysics, 57, 116-125. https://doi.org/10.1190/1.1443174

[41] MacLeod, I.N., Jones, K. and Dai, T.F. (1993) 3-D Analytic Signal in the Interpretation of Total Magnetic Field Data at Low Magnetic Latitudes. Exploration Geophysics, 24, 679-688. https://doi.org/10.1071/EG993679

[42] Reid, A.B., Allsop, J.M., Granser, H., Millett, A.J. and Somerton, I.W. (1990) Magnetic Interpretation in Three Dimensions Using Euler Deconvolution. Geophysics, 55, 80-90. https://doi.org/10.1190/1.1442774

[43] Telford, W.M., Telford, W.M., Geldart, L.P. and Sheriff, R.E. (1990) Applied Geophysics (Vol. 1). Cambridge University Press, Cambridge. https://doi.org/10.1017/CBO9781139167932

[44] Nzenti, J.P. (1987) Pétrogenèse des migmatites de Yaoundé (Cameroun). Eléments pour un modèle géodynamique de la chaine pan-africaine Nord Equatoriale. Thèse de Doctorat, Université de Nancy, France, 147 p. 